\title{
Delimitación de la responsabilidad de los servicios de intermediación de la sociedad de la información (I)
}

\author{
(PRIMERA PARTE) \\ (ORIGEN DEL PROBLEMA Y RÉGIMEN JURÍDICO GENERAL \\ EN EE. UU. Y UE)
}

\section{Fernando Carbajo Cascón}

Licenciado en Derecho; doctor en Derecho por la Universidad de Salamanca, España; Magistrado de la Audiencia Provincial (Corte de Apelación) de Salamanca. Profesor titular de Derecho Mercantil de la Universidad de Salamanca, España. Miembro del Grupo de Investigación "Derecho y Nuevas Tecnologías", Universidad de Salamanca. Colaborador del Grupo de Investigación E-LECTRA: Edición y Lectura Electrónica, Transferencia y Recuperación Automatizada de la Información, Universidad de Salamanca.Correo electrónico:nano@usal.es

\begin{abstract}
Resumen
La sociedad de la información exige que se fijen parámetros del alcance de las nuevas tecnologías en servicios de intermediación relacionados con el funcionamiento de la Red en ámbitos como comercio electrónico, contratación a distancia por medios electrónicos de bienes materiales e inmateriales y servicios tangibles e intangibles susceptibles de comercio. El siguiente texto Delimitación de la responsabilidad de los servicios de intermediación de la sociedad de la información plantea los retos a la intermediación en núcleos problemáticos que han sido tratados por el Derecho comparado en la legislación Norteamericana y Europea. Finalmente, hace un acercamiento a la legislación española y aborda el tema de los servicios de intermediación a partir de operadores de redes, proveedores de acceso, almacenamiento y alojamiento de datos.
\end{abstract}

Palabras clave: Comercio electrónico, servicios en línea, intermediación, medios electrónicos.

\begin{abstract}
The information society requires parameters of the scope of new technologies are set in brokering services related to the operation of the network in areas such as electronic commerce, distance contracting by electronic means of tangible and intangible assets and tangible and intangible services likely trading. The following demarcation of responsibility for the intermediary services of the information society poses challenges brokering core problems that have been treated by the comparative law in the American and European legislation. Finally zooms to the Spanish legislation and addresses the issue of intermediation services from network operators, service providers, storage and hosting.
\end{abstract}

Keywords: Ecommerce, Online services, brokerage, electronic media.

\section{Résumé}

La société de l'information nécessite des paramètres de la portée des nouvelles technologies sont prévues dans les services liés à l'exploitation du réseau dans des domaines tels que le commerce électronique , de contrats à distance par des moyens électroniques d'immobilisations corporelles et incorporelles et les services matériels et immatériels susceptibles de courtage négociation. La démarcation suivante de la responsabilité pour les services intermédiaires de la société de l'information pose des défis de courtage problèmes fondamentaux qui ont été traités par le droit comparé dans la législation américaine et européenne . Enfin zooms à la législation espagnole et aborde la question des services d'intermédiation auprès des opérateurs de réseaux, fournisseurs de services, le stockage et hébergement .

Mots-clés: Commerce, Services en ligne, Courtage, Services Électroniques, Online services. 



\title{
Delimitación de la responsabilidad de los servicios de intermediación de la sociedad de la información (I)*
}

\author{
(PRIMERA PARTE) \\ (ORIGEN DEL PROBLEMA Y RÉGIMEN JURÍDICO GENERAL \\ EN EE. UU. Y UE)
}

Fernando Carbajo Cascón

\section{PRELIMINAR: DELIMITACIÓN DE CONCEPTOS Y PROBLEMAS}

La privatización y globalización de internet a mediados de los años noventa generó, de manera casi inmediata, la creación de un espacio global virtual de intercambio de todo tipo de información y de un mercado o espacio comercial trasnacional donde se desarrollan todo tipo de operaciones comerciales mediante contratos (de compraventa, de licencia, entre otros) celebrados a distancia y por medios electrónicos. A todos los servicios ofrecidos a distancia por medios telemáticos, se les atribuyó la denominación de servicios de la sociedad de la información; concepto básico en el que están incluidos también los sitios de comercio electrónico, entendiendo por tales los sitios que ofrecen un servicio de contratación a distancia por medios electrónicos de todo tipo de bienes materiales e inmateriales, servicios o cualquier prestación tangible o intangible susceptible de comercio.

Pero la Red generó también, inmediatamente, la aparición de un tipo específico de servicios relacionados directamente con el funcionamiento mismo de la red de redes. En la llamada Web 1.0 estos servicios tenían un carácter exclusivamente técnico, ofreciendo la transmisión de datos a través de redes interconectadas, el acceso de los usuarios a internet, espacios de memoria para el almacenamiento de información, y servicios de búsqueda de información. A estos peculiares servicios técnicos se los bautizó con el nombre de servicios de intermediación de la sociedad de la información, aunque suelen conocerse generalmente por la denominación inglesa internet service providers (ISP). Tales servicios de intermediación, de

* El texto se deriva del trabajo sobre sociedad de la información del Grupo de Investigación: Derecho y Nuevas Tecnologías, Universidad de Salamanca, España. 
carácter -insisto- eminentemente técnico en sus orígenes, están en una relación de género-especie con el concepto básico o general de servicios de la sociedad de la información.

Este tipo de servicios de intermediación o intermediarios de la sociedad de la información ofrecen, como decimos, servicios técnicos consistentes en la transmisión, almacenamiento o búsqueda de datos en la Red a todos los usuarios (sean empresas, profesionales o consumidores y usuarios) que lo deseen. Normalmente son servicios de pago (acceso a internet y transmisión de datos; almacenamiento de datos en servidores y proporción de espacio web), pero también existen servicios gratuitos (algunos espacios de alojamiento de datos y motores de búsqueda). En cualquier caso, como todos los servicios de la sociedad de la información, se prestan a distancia y a petición del destinatario o usuario del servicio (a la carta o bajo demanda).

La legislación española (Anexo de la Ley 34/2002, de 11 de julio, de Servicios de la Sociedad de la Información y del Comercio Electrónico; LSSICE), que trae razón de la legislación comunitaria europea (Directiva 2000/31/CE, de 8 de junio, del Parlamento Europeo y del Consejo, relativa a determinados aspectos jurídicos de los servicios de la sociedad de la información, en particular el comercio electrónico en el mercado interior; DCE) ofrece un concepto claro de servicios de la sociedad de la información y de los servicios de intermediación.

Así, se entiende por servicio de la sociedad de la información todo servicio prestado normalmente a título oneroso, a distancia, por vía electrónica y a petición individual del destinatario, comprendiendo también los servicios no remunerados por sus destinatarios, en la medida en que constituyan una actividad económica para el prestador de servicios. Entre ellos, se incluyen los servicios de contratación de bienes o servicios por vía electrónica (servicios de comercio electrónico); la organización y gestión de subastas por medios electrónicos o de mercados y centros comerciales virtuales; la gestión de compras en la red por grupos de personas; el envío de comunicaciones comerciales; los servicios de suministro de información por vía telemática; el vídeo bajo demanda, como servicio en que el usuario pueda seleccionar a través de la red, tanto el programa deseado como el momento de su suministro y recepción, y, en general, la distribución de contenidos previa petición individual.

Los servicios de intermediación se configuran como una especie dentro del género de los servicios de la sociedad de la información, definiéndolos el mentado Anexo LSSICE 2002 como: aquellos servicios de la sociedad de la información por los que se facilita la prestación o utilización de otros servicios de la sociedad de la información o el acceso a la información. De modo que un servicio de intermediación se convierte en pieza clave para utilizar cualquiera de los otros servicios de la sociedad de la información. Se incluyen entre ellos los servicios de acceso a internet (internet service providers), los servicios de transmisión de datos por redes de telecomunicaciones (mere conduit o routing), los servicios que ofrecen la realización de copia temporal de las páginas de internet solicitadas por los usuarios (system 
caching o memoria tampón), los servicios de alojamiento en los propios servidores de datos, aplicaciones o servicios suministrados por terceros (hosting) y los servicios que ofrecen instrumentos de búsqueda, acceso y recopilación de datos o de enlaces a otros sitios de internet (searching \& linking).

Estos servicios de intermediación han estado vinculados a internet desde sus mismos orígenes, perfeccionándose con el paso de los años y la aparición de nuevas aplicaciones informáticas y telemáticas. Podría decirse, de hecho, que estos servicios de intermediación, nacidos al mismo tiempo de la llamada Web 1.0 son esenciales para el correcto funcionamiento de internet, entendida como una interconexión de redes de acceso y transmisión global. Sin estos servicios "técnicos", la internet no podría funcionar; o no tal y como la conocemos actualmente.

Con el paso de los años, la expansión y consolidación de la internet por todo el mundo (convirtiéndose en elemento fundamental de la vida de los ciudadanos, de la actividad publicitaria y comercial de las empresas y de otras entidades, y de la gestión de los Gobiernos) generó una cantidad inmanejable de información comercial y no comercial, cuyo acceso, clasificación y asimilación sería ingobernable sin la actividad de intermediarios. Este fenómeno, conocido como hipertrofia de información, cuya máxima expresión son las redes sociales y que se conoce generalmente bajo la denominación de Web 2.0, provocó la aparición gradual de nuevos servicios de intermediación cuya actividad ya no es exclusiva o estrictamente técnica, sino que ofrecen servicios de agregación de información dispersa a los usuarios de la Red; información que puede ser de mero consumo intelectual o de entretenimiento e incluso información personal (como sucede en las redes sociales del tipo YouTube o Facebook), o bien puede ser información comercial agregada (como realizan los grandes operadores de mercados virtuales como eBay o Amazon, y los grandes buscadores que ofrecen información publicitaria agregada como Google, Mozilla o Bing). Estos nuevos intermediarios-agregadores de información dispersa, actúan como grandes buscadores y alojadores de información dispersa para ofrecerla, agregada y organizada, a través de un único punto de acceso global, financiándose la mayoría de las veces indirectamente mediante publicidad.

Desde la aparición y consolidación de los servicios de intermediación comenzaron a plantearse problemas relacionados con la responsabilidad de tales servicios, no ya por infracciones cometidas en la prestación normal del mismo a sus usuarios directos, sino fundamentalmente por las infracciones de derechos cometidas por los usuarios del servicio. Es decir, no se trata solo de que los intermediarios de la sociedad de la información deban responder directamente por posibles incumplimientos contractuales y daños y perjuicios causados a terceros con motivo de la prestación de su servicio, sino también de decidir si deben, asimismo, responder por posibles violaciones de derechos que los usuarios de sus servicios de intermediación pueden causar a terceros con motivo del alojamiento y difusión de informaciones por la Red. Infracciones de derechos que pueden ir desde graves infracciones penales relacionadas con la pornografía infantil o la negación del holocausto nazi, hasta 
infracciones civiles al derecho al honor, la intimidad y la propia imagen, así como (frecuentes) violaciones de derechos de propiedad industrial e intelectual.

La responsabilidad de los intermediarios por los actos de los usuarios de su servicio generó desde un primer momento un intenso debate social y económico que acabó trasladándose a la jurisprudencia y a la legislación de los países más avanzados (principalmente EE.UU y los Estados miembros de la UE). Hoy día puede decirse que es un debate aún no cerrado, debido a las variaciones introducidas por la Web $2.0 \mathrm{y}$ por la aparición de nuevos tipos de intermediarios que no encajan adecuadamente en los parámetros marcados en la Legislación fraguada a finales del Siglo XX. El debate gira en torno al alcance de la responsabilidad de los intermediarios por los actos de sus usuarios, discutiéndose si es preciso sancionar en todo caso su responsabilidad, si, por el contrario, debe establecerse un régimen de exención de responsabilidad (de no responsabilidad) o si conviene delimitar un régimen ecléctico que combine los intereses de las víctimas a obtener adecuada compensación de los daños padecidos con el correcto funcionamiento de internet. Por tanto, el debate gira en torno a la naturaleza, alcance y régimen jurídico de la responsabilidad (o no responsabilidad) de los intermediarios de la sociedad de la información. Pero incluye también la oportunidad o no de exigir a estos intermediarios la colaboración con los perjudicados y con las autoridades públicas en la identificación de los usuarios infractores (en conflicto con el derecho a la intimidad y la normativa sobre protección de datos personales), y también en la ejecución de las resoluciones judiciales o administrativas dirigidas contra los usuarios infractores.

Durante los años noventa, la jurisprudencia estadounidense y de algunos países europeos (como Francia o Alemania) se pronunció indistintamente por exonerar o por imputar responsabilidad a los intermediarios por las infracciones cometidas por los usuarios de su servicio (Peguera, 2007, pp. 9, 175; Busto, 2003, pp. 971, 995). Inmediatamente, las decisiones judiciales contradictorias y la evidente relevancia de los servicios de intermediación para el correcto funcionamiento de internet, originaron un intenso debate entre la doctrina científica y el conjunto de la sociedad que acabó por demostrar la necesidad de legislar al respecto para garantizar la seguridad jurídica.

En el trasfondo de la decisión legislativa existe una intensa confrontación de intereses en juego. De un lado están los intereses de las víctimas a obtener del legislador una adecuada protección a sus intereses; especialmente en lo que respecta al derecho del honor, la intimidad y la imagen, así como las violaciones de derechos de propiedad industrial (marcas) y propiedad intelectual (derechos de autor y derechos conexos), tan importantes en la sociedad de la información. De otro lado está el juego de incentivos a la innovación tecnológica y el interés general en el correcto funcionamiento de internet; parece claro que establecer un sistema amplio de responsabilidad que obligue a los intermediarios a responder de los actos de los usuarios de su servicio, supone un desincentivo a la inversión en nuevas aplicaciones que mejoren el funcionamiento de la Red que, a corto o medio plazo, puede bloquear seriamente la arquitectura y funcionamiento de internet en detrimento de los intereses de millones de personas y organizaciones. 
El establecimiento de una obligación genérica de supervisión por parte de los PSI, desde el punto de vista jurídico, los convertiría en responsables cuasi objetivos (Garrote 2000, p. 56). El sistema se encarecería notablemente (con lo cual, los costes de control habrían de ser repercutidos, presumiblemente sobre los usuarios) y podría llegar a colapsarse, destruyendo la "tierra prometida virtual". Por lo demás, no todos los intermediarios dispondrían de los recursos necesarios a nivel técnico para controlar todos los datos que circulan por su sistema, lo cual dejaría el control de la Red en manos de unos pocos grupos poderosos multinacionales. En sentido contrario, una exención plena o absoluta de responsabilidad de los intermediarios de la sociedad de la información desplazaría todo el riesgo del flujo de contenidos ilícitos hacia los titulares de derechos, que estarían obligados a detectar todas las infracciones y proceder individualmente contra los infractores; algo que se antoja prácticamente imposible por razones de economía procesal y también por las políticas de protección de datos personales de los usuarios de redes, fundadas en el derecho a la privacidad de las comunicaciones (Clemente, 2003).

Desde una perspectiva de análisis económico del derecho, se confrontan las eficiencias sobre la innovación técnica y el bienestar de los consumidores que proporciona una legislación que exime de responsabilidad a los intermediarios de la sociedad de la información para garantizar el flujo de información y, con ello, la máxima libertad de expresión e información, con las eficiencias dinámicas que garantizan los derechos de propiedad industrial e intelectual a quienes invierten su tiempo, dinero y esfuerzo personal en la creación y explotación de bienes inmateriales fundamentales para la competitividad y el desarrollo social, económico y cultural. Esta confrontación hace que la materia en estudio se manifieste como una de las principales de nuestra era: la era del acceso a la información, pero también la era de la economía digital o economía de la información, jugando en ambos casos la información un papel fundamental desde la perspectiva de la libertad de expresión e información y desde la perspectiva de la tutela de derechos e intereses personales a la intimidad, el honor y la imagen y de derechos de propiedad intelectual (derechos de autor, patentes, marcas y diseños). De manera que la delimitación de la responsabilidad de intermediarios de la sociedad de la información se sitúa en el ojo del huracán, en el centro de la encrucijada que actualmente supone la tensión dialéctica entre la necesidad de favorecer la máxima difusión y el mayor acceso posible a la información a través de redes digitales y la necesidad de ofrecer una tutela a los creadores e inversores en bienes inmateriales para favorecer la innovación, la generación de información y el correcto funcionamiento de un mercado basado cada vez más en la ciencia, la cultura, la innovación y la información.

Fue así como los dos principales ordenamientos jurídicos del mundo movieron ficha rápidamente para legislar sobre la materia, optando desde un principio por garantizar el correcto funcionamiento de internet; es decir, optando por proteger a los intermediarios de la sociedad de la información excluyendo de antemano su responsabilidad por las infracciones a terceros cometidas por los usuarios de sus servicios, diseñando un régimen de defensa o "puerto seguro" para garantizar 
su funcionamiento, a salvo de constantes demandas de responsabilidad por la información suministrada por terceros, y con ello, el discurrir fluido de información de todo tipo a través de internet.

Ambos ordenamientos parten de un principio general de no responsabilidad o exención de responsabilidad de los intermediarios de la sociedad de la información, siempre que se den una serie de condiciones prestablecidas para cada tipo de servicios de intermediación; condiciones que tendrían por objetivo delimitar adecuadamente los intereses en juego que subyacen a cada actividad de intermediación, pues no pueden medirse de igual forma la mera transmisión de datos por internet, que proporcionar espacio de alojamiento en servidores para poner esa información a disposición del público desde los servidores del intermediario; o almacenar temporalmente información en memoria caché, que ofrecer servicios automáticos de búsqueda y directores de enlaces a informaciones. En caso de no darse las condiciones que justifican a priori la exención de responsabilidad de los intermediarios, estos pueden resultar responsables de los ilícitos cometidos por los usuarios de su servicio. Pero no puede decirse que esa responsabilidad se produzca automáticamente. Y además, esa posible "responsabilidad" de los intermediarios no necesariamente ha de ser una responsabilidad stricto sensu, es decir, una responsabilidad (civil, penal o administrativa) que recaiga directamente sobre su patrimonio, sino que dicha "responsabilidad" puede traducirse, según los casos, en la obligación de cesar en la prestación de su servicio al usuario infractor.

Como veremos a continuación, puede decirse que comparando la legislación estadounidense con la europea, parece que en esta última la responsabilidad civil potencial de los ISP es mayor que en la primera. Los problemas creados en torno a la posición que ocupan los intermediaros en la Web 2.0, encuentran mejor solución -al menos a priori- a fin de imputar responsabilidad al intermediario con la normativa europea que con la estadounidense. Sin embargo la normativa estadounidense es mucho más clara en lo que se refiere a los deberes de conducta de los intermediarios orientados a evitar infracciones de derechos de terceros; aunque este característica del ordenamiento estadounidense de debe al carácter vertical de su regulación (prevista únicamente en materia de honor e intimidad y de derechos de autor) frente a la aproximación horizontal del ordenamiento europeo comunitario (que hace más difícil establecer deberes concretos de vigilancia de contenidos).

El análisis de la delimitación de responsabilidades de los intermediarios de la sociedad de la información adquiere una especial trascendencia práctica en lo relativo a los servicios de hosting o alojamiento de datos.

Son muchas las obras que analizan en profundidad el origen y régimen jurídico de las legislaciones estadounidenses y europea en materia de responsabilidad de ISP, casi siempre prestando especial atención a los servicios de alojamiento de datos. Sin embargo, son pocos aún los estudios realizados sobre las fisuras del sistema de exención de responsabilidad, sobre todo, precisamente, en relación con los llamados servicios de Hosting Web 2.0, o servicios de alojamiento de datos no estrictamente o exclusivamente técnicos, en los que la aplicación generalizada e irreflexiva del 
régimen general de no responsabilidad corre el riesgo de consolidar regímenes de total impunidad por parte de intermediarios que, en muchos casos, basan su negocio en los comportamientos infractores de los usuarios de su servicio, en manifiesto detrimento de los derechos e intereses de los terceros perjudicados por esas infracciones (fundamentalmente derechos al honor, la intimidad y la propia imagen, derechos de marca y derechos de autor y conexos).

Por ello, tras exponer sucintamente los fundamentos y las claves de las dos principales legislaciones sobre la materia, centraremos este estudio en las posibilidades de imputación de responsabilidad a los intermediarios evolucionados, conocidos como agregadores de la sociedad de la información, característicos de la Web 2.0, y en particular a los ya mencionados Hosters Web 2.0, entre los que se encuentran muchos de los servicios más populares de los últimos años: Google AdWords, eBay, YouTube, Megaupload.com o Rapishare.com, y cualquiera de la multitud de webs de enlaces que facilitan la descarga directa de archivos con contenidos ilícitos, actuando así de engranaje fundamental en la piratería de contenidos.

\section{LA EXENCIÓN DE RESPONSABILIDAD DE LOS ISP EN ESTADOS UNIDOS DE AMÉRICA}

En EE. UU se promulgó en un primer momento la Communications Decency Act (CDA) de 1996, que modificó la Communications Act de 1934, añadiendo una nueva sección (Sect. 230) codificada como 47 U.S.C. 230. Esta nueva regulación tuvo por objetivo exonerar de responsabilidad a los ISP por las informaciones suministradas por los usuarios de su servicio, declarando que el ISP no puede ser tratado como un editor o locutor de materiales suministrados por terceros (Sect. 230.1) ${ }^{1}$, pero al mismo tiempo pretende estimular a los ISP para retirar o bloquear el acceso a contenidos ofensivos para terceras personas suministrados por los usuarios de su servicio, eximiéndole de responsabilidad frente a tales usuarios del servicio cuando el intermediario hubiera bloqueado o retirado los contenidos de buena fe (Sect. 230.2) (Peguera, 2007).

Poco tiempo después, ante el elevado número de reclamaciones derivadas de infracciones a derechos de autor cometidas a través de servicios de intermediación (desde proveedores de acceso a internet, a espacios de alojamiento o hosting/housing, pasando por motores de búsqueda), el Congreso estadounidense decidió incorporar a un nuevo régimen de exención de responsabilidad de intermediarios en la Copyright Act, lo cual tuvo lugar a través de la célebre Digital Millenium Copyright Act, de 28 de octubre de 1998 (DMCA).

1 Sect. 230 (1): No provider or user of an interactive computer service shall be treated as the Publisher or speaker of any information provided by another information content provider". Sect. 230 e (3):

"No cause of action may be brought and no liability may be imposed under any State or local law that is inconsistent with this section. 
Al igual que la CDA, esta Ley establece como principio general un régimen de exenciones de responsabilidad a determinadas actividades o servicios que prestan los ISP únicamente frente a la responsabilidad civil que se derive de infracciones de copyright, definiéndolas de forma precisa y estableciendo las condiciones para que en cada supuesto la regla general de exención de responsabilidad resulte aplicable. Como apunta la doctrina, estas reglas funcionan como lugar de cobijo o puerto seguro (safe harbor) en el que el intermediario puede recalar y operar con la tranquilidad de saber que si su actividad encaja en alguno de los supuestos contemplados, no resultará responsable de las infracciones de copyright cometidas por las informaciones de los usuarios de su servicio.

La nueva Sección 512 de la U.S Copyright Act, incorporada por la DMCA 1998 y codificada como 17 U.S Code 512, contiene cuatro supuestos de exclusión de responsabilidad de servicios de intermediación, agrupándose en cuatro subsecciones (Peguera, 2007): la transmisión de datos (Transitory Digital Network Communications; Sect. 512a) ${ }^{2}$; el almacenamiento de copias en memoria caché (System Caching; Sect. $512 \mathrm{~b})^{3}$; el alojamiento de información a solicitud del usuario (Information

2 Transitory Digital Network Communications.- A service provider shall not be liable for monetary relief, or, except as provided in subsection (j), for injunctive or other equitable relief, for infringement of copyright by reason of the provider's transmitting, routing, or providing connections for, material through a system or network controlled or operated by or for the service provider, or by reason of the intermediate and transient storage of that material in the course of such transmitting, routing, or providing connections, if-(1) the transmission of the material was initiated by or at the direction of a person other than the service provider; (2) the transmission, routing, provision of connections, or storage is carried out through an automatic technical process without selection of the material by the service provider; (3) the service provider does not select the recipients of the material except as an automatic response to the request of another person; (4) no copy of the material made by the service provider in the course of such intermediate or transient storage is maintained on the system or network in a manner ordinarily accessible to anyone other than anticipated recipients, and no such copy is maintained on the system or network in a manner ordinarily accessible to such anticipated recipients for a longer period than is reasonably necessary for the transmission, routing, or provision of connections; and (5) the material is transmitted through the system or network without modification of its content.

3 System Caching.- (1) Limitation on liability.- A service provider shall not be liable for monetary relief, or, except as provided in subsection (j), for injunctive or other equitable relief, for infringement of copyright by reason of the intermediate and temporary storage of material on a system or network controlled or operated by or for the service provider in a case in which - (A) the material is made available online by a person other than the service provider; (B) the material is transmitted from the person described in subparagraph (A) through the system or network to a person other than the person described in subparagraph (A) at the direction of that other person; and (C) the storage is carried out through an automatic technical process for the purpose of making the material available to users of the system or network who, after the material is transmitted as described in subparagraph (B), request access to the material from the person described in subparagraph (A), if the conditions set forth in paragraph (2) are met.

(2) Conditions. - The conditions referred to in paragraph (1) are that - (A) the material described in paragraph (1) is transmitted to the subsequent users described in paragraph (1)(C) without modification to its content from the manner in which the material was transmitted from the person described in paragraph (1)(A); (B) the service provider described in paragraph (1) complies with rules concerning the refreshing, reloading, or other updating of the material when specified by the person making the material available online in accordance with a generally accepted industry 
Residing on Systems or Networks at Direction of Users; Sect. 512c) ${ }^{4}$ y la provisión de herramientas de localización de información (Information Location Tools; Sect.

standard data communications protocol for the system or network through which that person makes the material available, except that this subparagraph applies only if those rules are not used by the person described in paragraph (1)(A) to prevent or unreasonably impair the intermediate storage to which this subsection applies; (C) the service provider does not interfere with the ability of technology associated with the material to return to the person described in paragraph (1)(A) the information that would have been available to that person if the material had been obtained by the subsequent users described in paragraph $(1)(C)$ directly from that person, except that this subparagraph applies only if that technology - (i) does not significantly interfere with the performance of the provider's system or network or with the intermediate storage of the material; (ii) is consistent with generally accepted industry standard communications protocols; and (iii) does not extract information from the provider's system or network other than the information that would have been available to the person described in paragraph (1)(A) if the subsequent users had gained access to the material directly from that person; (D) if the person described in paragraph (1)(A) has in effect a condition that a person must meet prior to having access to the material, such as a condition based on payment of a fee or provision of a password or other information, the service provider permits access to the stored material in significant part only to users of its system or network that have met those conditions and only in accordance with those conditions; and (E) if the person described in paragraph (1)(A) makes that material available online without the authorization of the copyright owner of the material, the service provider responds expeditiously to remove, or disable access to, the material that is claimed to be infringing upon notification of claimed infringement as described in subsection (c)(3), except that this subparagraph applies only if - (i) the material has previously been removed from the originating site or access to it has been disabled, or a court has ordered that the material be removed from the originating site or that access to the material on the originating site be disabled; and (ii) the party giving the notification includes in the notification a statement confirming that the material has been removed from the originating site or access to it has been disabled or that a court has ordered that the material be removed from the originating site or that access to the material on the originating site be disabled.

4 Information Residing on Systems or Networks At Direction of Users. - (1) In general. - A service provider shall not be liable for monetary relief, or, except as provided in subsection (j), for injunctive or other equitable relief, for infringement of copyright by reason of the storage at the direction of a user of material that resides on a system or network controlled or operated by or for the service provider, if the service provider-(A) (i) does not have actual knowledge that the material or an activity using the material on the system or network is infringing; (ii) in the absence of such actual knowledge, is not aware of facts or circumstances from which infringing activity is apparent; or (iii) upon obtaining such knowledge or awareness, acts expeditiously to remove, or disable access to, the material; (B) does not receive a financial benefit directly attributable to the infringing activity, in a case in which the service provider has the right and ability to control such activity; and (C) upon notification of claimed infringement as described in paragraph (3), responds expeditiously to remove, or disable access to, the material that is claimed to be infringing or to be the subject of infringing activity. 


\section{2d) ${ }^{5}$. La referida 17 U.S Code 512 excluye la responsabilidad de intermediarios respecto a la obligación de indemnizar económicamente (monetary relief, salvo posibles responsabilidades penales) $\mathrm{y}$, parcialmente, respecto a la posibilidad de}

(2) Designated agent. - The limitations on liability established in this subsection apply to a service provider only if the service provider has designated an agent to receive notifications of claimed infringement described in paragraph (3), by making available through its service, including on its website in a location accessible to the public, and by providing to the Copyright Office, substantially the following information: (A) the name, address, phone number, and electronic mail address of the agent. (B) Other contact information which the Register of Copyrights may deem appropriate. The Register of Copyrights shall maintain a current directory of agents available to the public for inspection, including through the Internet, and may require payment of a fee by service providers to cover the costs of maintaining the directory.

(3) Elements of notification.- (A) To be effective under this subsection, a notification of claimed infringement must be a written communication provided to the designated agent of a service provider that includes substantially the following: (i) A physical or electronic signature of a person authorized to act on behalf of the owner of an exclusive right that is allegedly infringed. (ii) Identification of the copyrighted work claimed to have been infringed, or, if multiple copyrighted works at a single online site are covered by a single notification, a representative list of such works at that site. (iii) Identification of the material that is claimed to be infringing or to be the subject of infringing activity and that is to be removed or access to which is to be disabled, and information reasonably sufficient to permit the service provider to locate the material. (iv)Information reasonably sufficient to permit the service provider to contact the complaining party, such as an address, telephone number, and, if available, an electronic mail address at which the complaining party may be contacted. (v) A statement that the complaining party has a good faith belief that use of the material in the manner complained of is not authorized by the copyright owner, its agent, or the law. (vi) A statement that the information in the notification is accurate, and under penalty of perjury, that the complaining party is authorized to act on behalf of the owner of an exclusive right that is allegedly infringed. (B) (i) Subject to clause (ii), a notification from a copyright owner or from a person authorized to act on behalf of the copyright owner that fails to comply substantially with the provisions of subparagraph (A) shall not be considered under paragraph (1) (A) in determining whether a service provider has actual knowledge or is aware of facts or circumstances from which infringing activity is apparent. (ii) In a case in which the notification that is provided to the service provider's designated agent fails to comply substantially with all the provisions of subparagraph (A) but substantially complies with clauses (ii), (iii), and (iv) of subparagraph (A), clause (i) of this subparagraph applies only if the service provider promptly attempts to contact the person making the notification or takes other reasonable steps to assist in the receipt of notification that substantially complies with all the provisions of subparagraph (A).

5 Information Location Tools.- A service provider shall not be liable for monetary relief, or, except as provided in subsection (j), for injunctive or other equitable relief, for infringement of copyright by reason of the provider referring or linking users to an online location containing infringing material or infringing activity, by using information location tools, including a directory, index, reference, pointer, or hypertext link, if the service provider-(1) (A) does not have actual knowledge that the material or activity is infringing; (B) in the absence of such actual knowledge, is not aware of facts or circumstances from which infringing activity is apparent; or (C) upon obtaining such knowledge or awareness, acts expeditiously to remove, or disable access to, the material; (2) does not receive a financial benefit directly attributable to the infringing activity, in a case in which the service provider has the right and ability to control such activity; and (3) upon notification of claimed infringement as described in subsection (c)(3), responds expeditiously to remove, or disable access to, the material that is claimed to be infringing or to be the subject of infringing activity, except that, for purposes of this paragraph, the information described in subsection (c)(3)(A)(iii) shall be identification of the reference or link, to material or activity claimed to be infringing, that is to be removed or access to which is to be disabled, and information reasonably sufficient to permit the service provider to locate that reference or link. 
exigirle la cesación del servicio (injuction relief, Sect. 512 j). Pero a cambio se pide a los prestadores de los citados servicios de intermediación una implicación activa en la defensa y protección de los derechos de autor, mediante una serie de deberes de conducta consistentes en la implementación de políticas de cooperación en la detección y retirada de contenidos infractores (notice \& takedown); esto es, que apliquen medidas razonables y eficaces para evitar en lo posible las infracciones de copyright. Estas medidas consisten, fundamentalmente, en la aplicación de sistemas de denuncia y retirada de contenidos infractores, complementada con políticas de expulsión de usuarios que sean reincidentes en la comisión de infracciones de derechos de propiedad intelectual, y, finalmente, con la obligación de respeto de las medidas tecnológicas utilizadas por los titulares del copyright para identificar y proteger sus contenidos intelectuales (Digital Rights Managment Systems; DRMS).

Por lo demás, la Subsección 512 m) de la U.S Copyright Act declara que no existe para los ISP una obligación general de supervisión de los contenidos o informaciones proporcionados por los usuarios de su servicio, a fin de detectar contenidos o datos ilícitos contra la propiedad intelectual de terceros (es decir, que no están obligados a desarrollar políticas de filtrado de datos), salvo que resulte estrictamente necesaria para exigir el respeto a los sistemas de protección técnica (DRMS) de derechos de autor. Pero esto no habilita al intermediario para permanecer pasivo si tiene conocimiento de la existencia de actividades o contenidos ilícitos en su red o sistema.

De las actividades de intermediación excluidas de la responsabilidad por los actos de sus usuarios tienen especial interés práctico las relativas al "hosting" o alojamiento de datos. Ello se debe a que en las actividades de transmisión de datos, en las de alojamiento temporal en memoria caché y en los motores de búsqueda, la presencia de contenidos infractores en la Red tiene un carácter temporal o incluso meramente transitorio (si no efímero), mientras que los servicios de alojamiento almacenan y permiten el acceso en red a quien lo desee a informaciones alojadas por los usuarios del servicio durante todo el tiempo que estos deseen, constituyendo así un riesgo potencial y real mucho mayor para los titulares de derechos.

De acuerdo con la Sección 512(c) 17 U.S.C. el proveedor de servicios de hosting no responderá de las infracciones derivadas de datos o informaciones alojados en su sistema por un usuario del servicio si se dan varias circunstancias (Peguera, 2007). En primer lugar $(512 \mathrm{c}, 1, \mathrm{~A})$ el hoster" no responderá si: i) no tiene conocimiento efectivo de que el material, o una actividad que utiliza ese material, es de carácter ilícito; ii) en el caso de no tener ese conocimiento efectivo, tampoco tiene conciencia de hechos o circunstancias que revelen la ilicitud de esos materiales o actividades; $y$ iii) en caso de adquirir conocimiento efectivo de la ilicitud o de conocer hechos o circunstancias reveladores de la actividad ilícita, procede de forma expeditiva para retirar el material o impedir el acceso al mismo. En segundo lugar (512, c, 1, B), en caso de que el proveedor de hosting tenga control de la actividad infractora, no puede recibir un beneficio económico directamente atribuible a la misma. Finalmente $(512, \mathrm{c}, 1, \mathrm{C})$, se dispone que el intermediario deberá retirar o bloquear de forma 
expeditiva el contenido infractor cuando reciba una notificación de infracción que cumpla los requisitos formales previstos en la Ley.

Las anteriores condiciones de exención de responsabilidad del proveedor de servicios de alojamiento solo serán efectivas $(512 \mathrm{c}, 2)$ si dicho proveedor pone a disposición de los titulares de derechos un servicio de notificación y retirada (Notice \& Takedown) gestionado por un agente encargado de recibir las notificaciones, informando de la existencia de dicho sistema y agente tanto al público como a la Copyright Office. Estas notificaciones son en realidad solicitudes de cesación en la prestación del servicio de alojamiento a usuarios que ponen a disposición del público contenidos o actividades infractores de los derechos del denunciante o de un tercero cuyos intereses representa. Estas notificaciones deben realizarse por escrito y dirigidas al agente designado por el proveedor de servicios de alojamiento, conteniendo las informaciones exigidas en la subsección 512(c)(3)(A), que están orientadas a identificar perfectamente al denunciante, el derecho supuestamente infringido, el contenido o material presuntamente infractor, datos de contacto del denunciante y una declaración formal y de buena fe de este señalando que el material denunciado no está autorizado por los titulares de derechos.

La retirada del material alojado o el bloqueo de acceso al mismo por parte del proveedor de servicios de alojamiento, no genera para este ninguna responsabilidad frente al usuario de su servicio que almacenó dicha información, siempre y cuando hubiera actuado de buena fe, basándose en una denuncia o notificación realizada con los requisitos legales, o bien en el conocimiento efectivo de la ilicitud o en el conocimiento de hechos o circunstancias reveladores de la actividad ilícita (Replacement of Removed or Disabled Material and Limitation on Other Liability; Sect. 512g).

Ahora bien, una vez eliminados dichos materiales, el proveedor debe informar lo antes posible de su retirada al titular del sitio donde estaban o a quien fuere su responsable, y si este mantiene que los está utilizando legítimamente, el proveedor vendría obligado nuevamente a activar el acceso al sitio, quedando eximido de responsabilidad tanto por la posible ilicitud de los contenidos como por la retirada de los mismos que llevó a cabo. Se trata de la llamada defensa del "buen samaritano". No obstante, si quien notificó la presunta infracción presenta demanda ante los Tribunales frente al infractor, el proveedor del espacio deberá retirar nuevamente el material a la espera de lo que decida el órgano jurisdiccional. La sucesiva trasgresión de estos deberes del proveedor en relación a cada una de las notificaciones y contra notificaciones efectuadas dará lugar a su posible responsabilidad. 


\section{LA DELIMITACIÓN DE RESPONSABILIDADES DE LOS INTERMEDIARIOS DE LA SOCIEDAD DE LA INFORMACIÓN EN LA LEGISLACIÓN EUROPEA Y ESPAÑOLA}

Frente a la aproximación vertical o por materias seguidas en los EE. UU., el legislador comunitario (por influencia de la Gesetz zur Regelung der Rahmenbedingungen für Informations- und Kommunikationsdienste alemana (IuKDG), de 22 de junio de 1997) optó por una aproximación horizontal o inespecífica del régimen de responsabilidad de los intermediarios de la sociedad de la información, trasladando esta consideración a los ordenamientos de los Estados miembros de la UE. De modo, entonces, que en Europa se parte de una responsabilidad general de los prestadores de servicios de la sociedad de la información, incluidos los servicios de intermediación, de carácter civil, penal y administrativo; aunque atendiendo a la peculiar posición de los intermediarios en el funcionamiento de internet, el legislador comunitario establece un régimen específico de responsabilidad para éstos que varía en función de las actividades que cada uno desempeña dentro del tráfico electrónico de información en la Red 6 .

Este régimen especial de responsabilidad se recoge en los arts. 12 a 15 de la Directiva 2000/31/CE de 8 de junio, del Parlamento Europeo y del Consejo, relativa a determinados aspectos jurídicos de los servicios de la sociedad de la información, en particular el comercio electrónico en el mercado interior (DCE). Y se incorporó a la legislación española por medio de la Ley 34/2002, de 11 de julio, de Servicios de la Sociedad de la Información y del Comercio Electrónico (LSSICE).

Al igual que en la legislación de los EE. UU., se parte de un principio general de exención de responsabilidad o no responsabilidad (régimen de puertos seguros) sujeto a una serie de condicionamientos que, de darse, podrían determinar la responsabilidad del intermediario; y dado el comentado carácter horizontal de la regulación, la responsabilidad puede ser civil, penal o administrativa cuando el intermediario lesione derechos e intereses legítimos de terceros con su actuación; aunque, sin duda, los principales problemas se plantean en la responsabilidad civil, por cuanto en casos de responsabilidad penal y administrativa la legislación comunitaria y española puede forzar a los intermediarios a desvelar la identidad de los usuarios de su servicio, quienes responderían exclusivamente salvo que se demostrase una connivencia o participación del intermediario en el ilícito; no así en la responsabilidad civil, donde la legislación española y otras comunitarias optan por tutelar preferentemente la privacidad de las comunicaciones (no exigiendo a los

6 Para un análisis general del régimen de los prestadores de servicios de intermediación de la sociedad de la información en la Directiva 200/31/CE, de 8 de junio, y en la Ley española 34/2002, de 11 de julio, de Servicios de la Sociedad de la Información y del Comercio Electrónico, con referencias también a otros ordenamientos de Estados miembros de la Unión Europea (Peguera, 2007; Busto, 2003; Moncada, 2009). 
intermediarios que colaboren con los perjudicados identificando a los usuarios de su servicio que infringen derechos de aquellos) frente a los legítimos derechos de las víctimas.

La DCE regula en concreto la responsabilidad (o no responsabilidad) de los servicios de transmisión de datos (art. 13 DCE), de los servicios de memoria caché (art. 13 DCE) y de los servicios de alojamiento de datos (art. 14 DCE). A diferencia del ordenamiento estadounidense (Sect. 512d), la Directiva comunitaria no contempla el supuesto de responsabilidad de los prestadores de servicios que faciliten instrumentos de búsqueda o enlaces (links) a contenidos o actividades de terceros. Sin embargo, el Considerando No. 21 (Preámbulo) cuando establece la necesidad de reexaminar la Directiva en los plazos establecidos en el mismo, dispone en su apartado $2^{\circ}$ que el informe de adaptación "analizará especialmente la necesidad de presentar propuestas relativas a la responsabilidad de los proveedores de hipervínculos y servicios de instrumentos de localización". Ahora bien, el legislador comunitario no impedía a los Estados miembros que, al incorporar la Directiva a sus ordenamientos internos, regulasen de forma expresa la responsabilidad de los proveedores de servicios de búsqueda y directorios de enlaces. La LSSICE española de 2002 que incorporó la Directiva comunitaria, tras declarar en su art. 13 que todos los prestadores de servicios de la sociedad de la información están sujetos a la responsabilidad civil, penal y administrativa establecida con carácter general en el ordenamiento jurídico, establece el régimen específico de responsabilidad de intermediarios de la sociedad de la información en los artículos siguientes, regulando así la responsabilidad de los operadores de redes y proveedores de de acceso (art. 14 LSSICE), de los prestadores de servicios que realizan copia temporal de los datos solicitados por los usuarios (art. 15 LSSICE), de los prestadores de servicios de alojamiento o almacenamiento de datos (art. 16 LSSICE) y de los prestadores de servicios que facilitan enlaces a contenidos o instrumentos de búsqueda (art. 17 LSSICE). Vemos pues, cómo el legislador español -sin duda, acertadamente- decidió adelantarse a esas futuras revisiones de la Directiva ${ }^{7}$, incluyendo en el art. 17 LSSICE la responsabilidad de los prestadores que faciliten enlaces a contenidos o instrumentos de búsqueda (Carbajo, $2004)^{8}$.

$7 \quad$ Aunque la Directiva de Comercio Electrónico es una Directiva de mínimos (Cdo. 10, DCE). Por lo tanto, siempre que se respeten los principios y objetivos básicos de la Directiva comunitaria, el legislador nacional puede establecer normas adicionales que sirvan al objetivo común del conseguir el correcto despliegue de los servicios de la sociedad de la información y, en particular, del comercio electrónico, garantizando la seguridad jurídica.

8 A diferencia de la legislación estadounidense (Sect. 512 (d) Copyright Act), que dispone como sujeto pasivo del régimen de responsabilidad a los proveedores de servicios (service provider) en el sentido de intermediarios de servicios de internet (internet service providers, ISP), y a diferencia también de lo que sucede con los otros supuestos de responsabilidad previstos en la Sección $2^{\circ}$ del Capítulo II LSSICE, el art. 17 no hace referencia únicamente a los prestadores de servicios de intermediación cuya actividad consiste en facilitar la prestación o utilización de otros servicios de la sociedad de la información o el acceso a la información en general mediante la provisión de instrumentos de búsqueda, acceso y recopilación de datos o de enlaces a otros sitios de internet, 
La normativa europea, como la estadounidense, establece criterios de exoneración de responsabilidad que, de incumplirse, podrán determinar la responsabilidad del intermediario, tomando como referencia la actividad o función desarrollada por cada tipo de intermediario en el proceso de acceso, almacenamiento y transmisión de datos en las comunicaciones electrónicas por internet. Pero es posible que un mismo prestador de servicios desempeñe varias actividades de intermediación en la Red (v.gr., servicios de acceso a internet y servicios de alojamiento de datos), con lo cual podrá exonerarse de responsabilidad por todos ellos, exonerarse en algunos y responder de otros, o responder por todos ellos. Incluso podrá responder directamente por contenidos elaborados o encargados a terceros por él mismo que almacena y difunde a través de su sistema o servicio. En suma, los criterios de imputación y exoneración de responsabilidad se aplicarán en tal caso en función de la actividad contemplada en cada momento.

No se sienta ninguna presunción de conocimiento de la ilicitud de los datos o actividades suministrados por los usuarios del servicio de intermediación? 9 . En particular, la Directiva comunitaria no regula de forma expresa (a diferencia de la estadounidense, donde constituye pieza clave) la obligación de los intermediarios de implementar un sistema de notificación y retirada de contenidos ilícitos, el legislador europeo, debido al carácter horizontal de la regulación (frente a la DMCA, centrada en la infracción de derechos de propiedad intelectual) ha preferido dejar a la autorregulación de los ISP la posibilidad de emplear sistemas de notice \& takedown, sin establecer condiciones de ningún tipo sobre el procedimiento para seguir y sobre la influencia de tales sistemas a la hora de enjuiciar la existencia o no de conocimiento efectivo en el intermediario de datos o actividades ilícitas de los usuarios de su servicio.

En cuanto al tipo de responsabilidad, aunque la Directiva no aclara nada al respecto de su texto, se deduce que los prestadores de servicios de intermediación responden

sino que el régimen de responsabilidad se hace extensivo a cualquier prestador de servicios de la sociedad de la información que facilite esos instrumentos de búsqueda de información (programas buscadores, directorios, entre otros) y/o hiperenlaces a sitios de terceros, no siendo esa su única o principal actividad. Lo cual es tanto como decir todos los prestadores de servicios de la sociedad de la información, pues será raro encontrar, en el inabarcable y caótico mundo virtual instaurado en la Red, un prestador de servicios de la sociedad de la información que no incorpore en su sitio y entre sus contenidos instrumentos de búsqueda o, sobre todo, enlaces a sitios y contenidos de terceros. Eso sí, no quedan incluidos en la norma (por no quedar incluidos en el ámbito de aplicación de la LSSICE) los titulares de sitios web u otros sitios en línea que, en rigor, no sean prestadores de servicios de la sociedad de la información, es decir, titulares de sitios en línea que no desarrollan una actividad económica en sentido muy amplio (art. 2 y letras a) y c) del Anexo de definiciones de la LSSICE).

9 No obstante, la Directiva 2000/31/CE prevé la posibilidad de que los Estados miembros establezcan determinados deberes de diligencia exigibles a los PSSI en el desarrollo de sus actividades cuyo incumplimiento sí generaría la oportuna responsabilidad. Igualmente, podrán exigirse responsabilidades si el prestador se somete de forma voluntaria a ciertos códigos de conducta que le obliguen a controlar los contenidos con los que trabaja, cuando estos resulten ser ilícitos. 
por sus propias actividades y no por hechos ajenos (Aparicio, 2003) ${ }^{10}$. Esto es, que su posible responsabilidad será por su comportamiento en el almacenamiento y difusión de contenidos propios o elaborados por él mismo o por cuenta suya ${ }^{11}$, pero también por los actos destinados a facilitar, sin control alguno, las informaciones y actividades de los usuarios de su sistema, distinta, por tanto, de la responsabilidad que corresponda a los usuarios por los ilícitos cometidos contra derechos e intereses de terceros ${ }^{12}$. De esta manera, la responsabilidad de los operadores de redes y proveedores de acceso es una responsabilidad por hecho propio de índole subjetiva (el mismo régimen de exención de responsabilidad excluye a priori una calificación de su responsabilidad como cuasi-objetiva u objetiva); cuestión distinta es que los datos o información causantes del daño a terceros provengan de terceros sujetos. Quiere esto decir que la responsabilidad civil, penal o administrativa no les será impuesta por el mero hecho de que un proveedor de contenidos o cualquier particular realice conductas que son punibles utilizando los servicios y recursos técnicos provistos por los PSI (lo que nos llevaría a una responsabilidad objetiva, por el mero riesgo que supone su actividad), sino por sus propias actuaciones en relación con tales conductas y la diligencia mostrada en evitarlas o impedirlas una vez descubiertas (Busto, 2003) ${ }^{13}$. Así pues, el intermediario de la sociedad de la información puede responder por acción u omisión propias en todo caso, pero -como se ha dicho ya- no responderá en ningún caso por el incumplimiento de una genérica obligación de supervisión de contenidos, que no puede exigírsele a priori por impedirlo el art. 15 DCE.

En este sentido, siguiendo la estela del legislador USA, la legislación comunitaria (art. 15.1 DCE) no impone a los prestadores de servicios de intermediación una obligación general de control o supervisión de los datos que almacenan o transmiten, siempre que desempeñen una labor de mera intermediación y no hayan contribuido a la creación de los contenidos ilícitos ${ }^{14}$. De hecho, el establecimiento de un deber

10 El único supuesto establecido en la norma de responsabilidad por hecho ajeno es la actuación del prestador del servicio (contenidos) bajo la dirección, autoridad o control del prestador del servicio de intermediación, en el caso de los prestadores de servicios de alojamiento (art. 12.1 letra b. DCE; art. 16.2 LSSICE) y prestadores de servicios de búsqueda (art. 17.2 LSSICE), de forma similar a la responsabilidad del art. $1903 \mathrm{CC}$.

11 Esto según Sentencia del Juzgado de Primera Instancia núm. 42 de Madrid, de 15 de junio de 2005, estimando la demanda contra el sitio www.putasgae.com, que actuaba como portal para recoger opiniones, muchas de ellas injuriosas contra el honor de la entidad de gestión colectiva de derechos de autor.

12 En contra Rubí (2010), para quien la responsabilidad del intermediario es una responsabilidad por hecho ajeno (por las infracciones cometidas por los usuarios del servicio).

13 Este autor habla al respecto de los principios de "autorresponsabilidad", "cooperación" y "reacción diligente". Ver también (Garrote, 2000, p. 49, en relación con los proveedores de espacio de alojamiento de datos).

14 Así lo ha confirmado la Sentencia del Tribunal de Justicia de la Unión Europea (STJUE) de 24 de noviembre de 2011 (As. C-70/2010, Scarlet), estableciendo que la legislación comunitaria de comercio electrónico, derechos de autor en la sociedad de la información y tratamiento de datos personales y protección de la privacidad en el ámbito de las comunicaciones electrónicas, debe interpretarse, leídas conjuntamente, en el sentido de que se oponen a un requerimiento judicial 
genérico de supervisión podría lesionar seriamente derechos básicos como el derecho a la intimidad, la libertad de expresión, la libertad de información, la protección de datos y la privacidad de las comunicaciones o la libre competencia (Barceló y Koelman, 2000). Y la consecuencia sería que los intermediarios de transmisión intervendrían de forma demasiado activa en el control a priori de contenidos, convirtiéndose en juez y parte y suspendiendo el servicio a la mínima sospecha para evitar así su responsabilidad, quedando sujetos, sin embargo, a ser demandados por los titulares de la información bloqueada o suspendida quienes alegarían vulneraciones a la libertad de expresión y a la libre competencia, además, por supuesto de incumplimiento contractual. Cuestión diferente es que los operadores de transmisión de datos actúen de motu propio al respecto, implementando programas de filtrado que detectan expresiones en la información que pueden indicar la existencia de contenidos ilícitos para proceder a su bloqueo siquiera preventivo. Actuación preventiva que, en muchas ocasiones, es fruto de la adhesión a códigos de buena conducta o códigos de práctica por parte de estos intermediarios ${ }^{15}$.

No obstante lo anterior, indica el apartado $2^{\circ}$ del mismo art. 15 DCE que los Estados miembros podrán establecer obligaciones tendentes a que los prestadores de servicios de la sociedad de la información comuniquen con prontitud a las autoridades públicas competentes los presuntos datos ilícitos o las actividades ilícitas llevadas a cabo por destinatarios de su servicio o la obligación de comunicar a las autoridades competentes, a solicitud de estas, información que les permita identificar a los destinatarios de su servicio con los que hayan celebrado acuerdos de almacenamiento. Pero vemos cómo la legislación comunitaria no impone un deber general de colaboración de los prestadores de servicios de intermediación en la sociedad de la información para la identificación de los usuarios que cometen ilícitos a través de su servicio o sistema, dejando la decisión final a los Estados miembros,

por el que se ordena a un proveedor de Internet establecer un sistema de filtrado de todas las comunicaciones electrónicas que circulen a través de sus servicios (en particular mediante la utilización de programas peer to peer de intercambio de archivos con contenidos protegidos por derechos de autor) y que se aplique indistintamente a toda su clientela, con carácter preventivo, exclusivamente a sus expensas y sin limitación de tiempo, con la finalidad de identificar en la red o sistema de dicho proveedor la circulación de archivos electrónicos que contengan copias no autorizadas de obras protegidas por derechos de autor, con la finalidad de bloquear la circulación de dichos archivos. En el mismo sentido se pronuncia la STJUE de 16 de febrero de 2012 (As. C-360/2010, SABAN c. Netlog NV).

15 De hecho, el legislador comunitario considera que la Directiva de comercio electrónico debería constituir una base adecuada para elaborar mecanismos rápidos y fiables que permitan retirar información ilícita y hacer que sea imposible acceder a ella, conviniendo que tales mecanismos se elaborasen tomando como base acuerdos voluntarios negociados entre todas las partes implicados y fomentados por los Estados miembros. Se entiende, en definitiva, que lo dispuesto en la DCE sobre responsabilidad no supone un obstáculo para que las distintas partes interesadas desarrollen y apliquen de forma efectiva sistemas técnicos de protección e identificación y de supervisión que permite la tecnología digital (Cdo. 40 DCE). 
que podrán incorporar ese deber de cooperación en sus respectivos ordenamientos internos con el alcance que consideren conveniente. La Sentencia de 29 de enero de 2008 (Gran Sala) del Tribunal de Justicia de las Comunidades Europeas (As. C-275/06, Promusicae c. Telefónica), señala que las Directivas comunitarias sobre comercio electrónico, derechos de autor en la sociedad de la información y protección de datos y tutela de la privacidad en las comunicaciones electrónicas, no obligan a los Estados miembros a imponer en su legislación interna el deber de comunicar datos personales con objeto de garantizar la protección efectiva de los derechos de autor en el marco de un procedimiento civil, aunque reconoce que el derecho a la intimidad y a la privacidad de las comunicaciones no está por encima del derecho de propiedad (intelectual) y que, en consecuencia, en la búsqueda de un justo equilibrio entre ambos, la normativa comunitaria no excluye la facultad de los Estados miembros para implementar mecanismos legales que impongan a los prestadores de servicios de acceso la obligación de comunicar los datos personales de los usuarios de sus servicios con el objeto de garantizar la protección efectiva de los derechos de propiedad intelectual en procedimientos civiles. A diferencia de otros países (como Suecia, Francia y Reino Unido, que tras la promulgación de la referida sentencia modificaron sus legislaciones para obligar a los intermediarios de la sociedad de la información, principalmente proveedores de acceso y de servicios de alojamiento, a identificar a los titulares de una dirección IP usuarios de sus servicios de intermediación a instancias de un órgano judicial o administrativo que, a su vez, hubiera recibido una petición fundada de los titulares de derechos de autor y conexos), el legislador español no ha querido hacer uso de esa opción, y ha preferido preservar la intimidad y la privacidad de las comunicaciones. La Ley 25/2007 de 18 de octubre, de conservación de datos relativos a las comunicaciones electrónicas y a las redes públicas de comunicación, dispone que los operadores de telecomunicaciones tienen un deber de cesión de datos generados en el marco de la prestación de sus servicios a los agentes facultados siempre que les sean requeridos a través de la correspondiente autorización judicial con fines de detección, investigación y enjuiciamiento de delitos graves contemplados en el Código Penal o en las leyes penales especiales, quedando fuera de ese deber de colaboración, por tanto, la cesión de datos de usuarios del servicio cuando las infracciones subyacentes a la solicitud de identificación no sean delitos graves (entre los que cuentas, precisamente, los delitos contra la propiedad industrial e intelectual) o sean infracciones administrativas o civiles (ilícitos contra la propiedad industrial e intelectual y contra el derecho al honor, la intimidad y la propia imagen) $)^{16}$.

16 La Disposición final cuadragésima tercera de la Ley 2/2011 de 4 de marzo, de Economía Sostenible, ha creado un órgano administrativo (Sección segunda de la Comisión de Propiedad Intelectual) para decidir sobre la retirada de contenidos y cierre de sitios en línea donde se produzcan infracciones de derechos de propiedad intelectual. No podrá dirigirse contra usuarios finales que descarguen archivos con contenidos no autorizados, sino contra los prestadores de servicios de la sociedad de la información (sitios web, blogs, chats, entre otros) que pongan a disposición del público 
No contempla tampoco expresamente la Directiva posibles acciones de cesación dirigidas contra los intermediarios. Posteriormente, visto el uso masivo y creciente de algunos servicios de intermediación por parte de los usuarios para vulnerar derechos de propiedad industrial e intelectual, la Directiva 2001/29/CE de 22 de mayo, de derechos de autor y derechos afines en la sociedad de la información (DDASI), dispuso en su art. 8.2 que los Estados miembros están obligados a adoptar las medidas necesarias para garantizar que los titulares de los derechos cuyos intereses se vean perjudicados por una actividad ilícita llevada a cabo en su territorio, puedan interponer una acción de resarcimiento de daños, así como la posibilidad de solicitar alternativa o cumulativamente medidas cautelares en orden a evitar que prosiga la realización de la actividad ilícita dañosa y, en su caso, la incautación del material ilícito. A continuación, el apartado $3^{\circ}$ del mismo art. 8 DDASI establece que los Estados miembros velarán por que los titulares de los derechos estén en condiciones de solicitar medidas cautelares contra los intermediarios a cuyos servicios recurra un tercero para infringir un derecho de autor o un derecho afín a los derechos de autor.

Este tipo de medidas se generalizaron más tarde para la tutela de derechos de propiedad industrial e intelectual, por medio del art. 9.1 de la Directiva 2004/48/ $\mathrm{CE}$, de 29 de abril, relativa al respeto de los derechos de propiedad intelectual, disponiendo que los mandamientos judiciales destinados a prevenir cualquier infracción inminente de aquellos derechos, también podrán dictarse, además de contra el presunto infractor, contra el intermediario cuyos servicios sean utilizados por un tercero para infringir un derecho de propiedad intelectual. De manera que los ISP podrán ser demandados en cesación u objeto de medidas cautelares con vistas a impedir que comportamientos infractores de legítimos derechos de propiedad industrial (marcas, patentes, diseños) o propiedad intelectual (derechos de autor y derechos afines) lleguen a realizarse o sigan realizándose a través de los servicios de intermediación, estando los prestadores de éstos a colaborar para evitar que esas infracciones sigan cometiéndose, pudiendo obligarles, llegado el caso, a cumplir forzosamente con ese deber de colaboración (retirada de contenidos, bloqueo de acceso a esos contenidos ilícitos, e incluso, llegado el caso, cierre provisional o definitivo del sitio de intermediación) (González, 2006; Busto, 2003).

En España, la Ley 56/2007 del 28 de diciembre, sobre medidas de impulso de la sociedad de la información, modificó el art. 11 LSSICE para establecer medidas concretas de colaboración de los prestadores de servicios de intermediación con las

contenidos ilícitos que violen derechos de autor y conexos. En ocasiones no será fácil identificar a los titulares de estos servicios de la sociedad de la información, razón por la que se ha modificado el art. 8 LSSICE para obligar a los prestadores de servicios de intermediación (fundamentalmente proveedores de acceso y de servicios de alojamiento) a identificar a los usuarios de sus servicios que sean prestadores de servicios de la sociedad de la información y estén vulnerando derechos de autor; ello tendrán que hacerlo a requerimiento judicial (jurisdicción contencioso-administrativa), previa solicitud del órgano administrativo competente (Sección Segunda de la Comisión de Propiedad Intelectual). 
autoridades públicas judiciales o administrativas. Establece el apartado $1^{\circ}$ del citado art. 11 LSSICE que cuando un órgano competente hubiera ordenado, en ejercicio de las competencias que legalmente tenga atribuidas, que se interrumpa la prestación de un servicio de la sociedad de la información o la retirada de determinados contenidos provenientes de prestadores establecidos en España, y para ello fuera necesaria la colaboración de los prestadores de servicios de intermediación, dicho órgano podrá ordenar a los citados prestadores que suspendan el correspondiente servicio de intermediación utilizado para la provisión del servicio de la sociedad de la información o de los contenidos cuya interrupción o retirada hayan sido ordenados respectivamente. Aunque no lo menciona expresamente, se está dando cobertura general (no solo para los ilícitos contra propiedad intelectual e industrial) a la posibilidad de que se ordene a los intermediarios la interrupción o bloqueo de un determinado servicio de la sociedad de la información (web, blog, chat, entre otros) prestador desde su sistema, o bien la retirada de determinados contenidos, datos o informaciones infractores de derechos e intereses de terceros. Ello se podrá hacer mediante acciones de cesación específicas contempladas en la legislación especial (marcas, diseños, derechos de autor y conexos, competencia desleal) o mediante medidas cautelares ordenadas con base en la misma legislación especial o en la legislación procesal general.

También, el apartado 2 del art. 11 LSSICE dispone que si para garantizar la efectividad de la resolución que acuerde la interrupción de la prestación de un servicio o la retirada de contenidos procedentes de un prestador establecido en un Estado no perteneciente a la Unión Europea o al Espacio Económico Europeo, el órgano competente estimará necesario impedir el acceso desde España a los mismos, y para ello será necesaria la colaboración de los prestadores de servicios de intermediación establecidos en España; dicho órgano podrá ordenar a los citados prestadores de servicios de intermediación que suspendan el correspondiente servicio de intermediación utilizado para la provisión del servicio de la sociedad de la información o de los contenidos cuya interrupción o retirada hayan sido ordenados respectivamente. De modo que un juez o autoridad administrativa española podrá ordenar a los intermediarios de la sociedad de la información (básicamente operadores de redes y prestadores de servicios de almacenamiento temporal o caching) que impida el acceso desde España a sitios en línea de terceros países que infringen derechos e intereses legítimos de nacionales o residentes en España ${ }^{17}$.

17 Medida que se antoja fundamental para combatir el fenómeno de la piratería global de contenidos, pues muchos de los contenidos que violan derechos de propiedad intelectual o industrial proceden de sitios en línea alojados en servidores de terceros países, muchos de ellos convertidos en auténticos paraísos informáticos. 


\section{OPERADORES DE REDES Y PROVEEDORES DE ACCESO}

La responsabilidad de los operadores de redes y proveedores de acceso es tratada de forma conjunta en el $12 \mathrm{DCE}^{18}$ y en el art. $14 \mathrm{LSSI}^{19}$. Los operadores de redes disponen la infraestructura básica para la circulación de los datos en forma electrónica (cableado, satélites, nodos, entre otros). En la práctica, la mayoría de los operadores de telecomunicaciones son los tradicionales operadores de redes telefónicas, dado que el acceso a internet se realiza fundamentalmente a través de tales redes, aunque en los últimos años nuevos operadores han desarrollado redes propias de fibra óptica o redes inalámbricas (wifi). En la práctica también es habitual que los operadores de redes ofrezcan servicio de acceso a internet, e incluso servicios integrales de acceso, memoria caché, alojamiento de datos y transmisión de datos.

La particularidad de las actividades de los operadores de redes y los proveedores de acceso radica en que desempeñan funciones de mera transmisión (mere conduit, en la terminología de la DCE). Es decir, sirven al proceso de intercambio de paquetes de datos mediante la puesta a disposición a todos los destinatarios de sus servicios (sean prestadores de servicios de intermediación, o sean meros particulares que faciliten contenidos y los destinatarios, a su vez, de los mismos) de la infraestructura de acceso a la Red desde el ordenador del usuario y la posterior transmisión de datos. Por tales razones, la LSSI (art. 14), en concordancia con el art. 12 de la DCE, establece la no responsabilidad de operadores de redes y proveedores de acceso por la información transmitida. Esta exención genérica de responsabilidad incluye el almacenamiento

18 Mera transmisión. 1. Los Estados miembros garantizarán que, en el caso de que un servicio de la sociedad de la información que consista en transmitir en una red de comunicaciones, datos facilitados por el destinatario del servicio o en facilitar acceso a una red de comunicaciones, no se pueda considerar al prestador de servicios de este tipo responsable de los datos transmitidos, a condición de que el prestador de servicios: a) no haya originado él mismo la transmisión; b) no seleccione al destinatario de la transmisión; y c) no seleccione ni modifique los datos transmitidos. 2. Las actividades de transmisión y concesión de acceso enumeradas en el apartado 1 engloban el almacenamiento automático, provisional y transitorio de los datos transmitidos siempre que dicho almacenamiento sirva exclusivamente para ejecutar la transmisión en la red de comunicaciones y que su duración no supere el tiempo razonablemente necesario para dicha transmisión. 3. El presente artículo no afectará a la posibilidad de que un tribunal o una autoridad administrativa, de conformidad con los sistemas jurídicos de los Estados miembros, exija al prestador de servicios que ponga fin a una infracción o que la impida.

19 Responsabilidad de los operadores de redes y proveedores de acceso. 1. Los operadores de redes de telecomunicaciones y proveedores de acceso a una red de telecomunicaciones que presten un servicio de intermediación que consista en transmitir por una red de telecomunicaciones datos facilitados por el destinatario del servicio o en facilitar acceso a esta no serán responsables por la información transmitida, salvo que ellos mismos hayan originado la transmisión, modificado los datos o seleccionado estos o a los destinatarios de dichos datos. No se entenderá por modificación la manipulación estrictamente técnica de los archivos que alberguen los datos, que tiene lugar durante su transmisión. 2. Las actividades de transmisión y provisión de acceso a que se refiere el apartado anterior incluyen el almacenamiento automático, provisional y transitorio de los datos, siempre que sirva exclusivamente para permitir su transmisión por la red de telecomunicaciones y su duración no supere el tiempo razonablemente necesario para ello. 
automático, provisional y transitorio de los datos (actividad conocida como routing), siempre que sirva exclusivamente para permitir la transmisión de los mismos por la red y no supere el tiempo razonable para ello. Ahora bien, los operadores de redes y proveedores de acceso no responderán, salvo que ellos mismos hayan originado la transmisión, modificado los datos o seleccionado estos o a sus destinatarios.

Así pues, en este caso, los supuestos de imputación de responsabilidad establecidos por la Ley solo concurren si los operadores de redes o los proveedores de acceso actúan como proveedores de contenidos o colaboran activamente en la difusión de estos, o bien cuando modifiquen esos contenidos sin el consentimiento de los titulares de derechos. En tales casos, podrán incurrir en responsabilidad, pero no por el hecho de su actividad de intermediación en el acceso a internet o en la transmisión de datos, sino por su participación efectiva y demostrable en la generación o puesta a disposición de información ilícita contra derechos e intereses de terceros o por la modificación de información de terceros ${ }^{20}$. Como apunta la doctrina, la selección de datos o destinatarios pone de manifiesto, en definitiva, una cierta capacidad de control de los mismos que hace a estos proveedores partícipes del ilícito, en cuanto podían haberlo evitado (Aparicio, 2003, p. 104).

La solución parece razonable, en tanto estos ISP se limitan por lo general a poner a disposición los medios técnicos (soportes materiales, conexiones) para que otros prestadores de servicios de la sociedad de la información oferten sus servicios a los destinatarios o para que los propios usuarios finales "suban" y "bajen" archivos a la red, no interviniendo en los contenidos que viajan por sus fibras o están temporalmente en sus ordenadores (solo el tiempo necesario para llevarlos desde el servidor al cliente, reducido en ocasiones a milisegundos); por lo que no pueden, desde el punto de vista práctico, ejercitar ningún control de contenido. Una solución contraria haría inviable el funcionamiento de la internet. También sería, si no

20 No se entiende por modificación la mera manipulación técnica de los archivos o datos que alberguen los servidores de estos PSSI cuando dicha operación sea necesaria para la transmisión. El manejo no imputable consistirá, habitualmente, en el fraccionamiento (los archivos de datos se "trocean" para su envío, y son recompuestos en destino) y el redireccionamiento de los paquetes de datos, tareas que se llevan a cabo de forma automática y sin intervención humana, así como su almacenamiento temporal (efímero o, en la repetitiva terminología de la LSSI, provisional y transitorio) cuando fuere necesario por razones técnicas (sin voluntad de realizar conducta ninguna que altere dichos archivos o de alargar el tiempo de almacenamiento). Considerando N. ${ }^{\circ} 43$ y art. 12.2 DCE. A mayor abundamiento, y por lo que respecta a las copias efímeras de obras sometidas al régimen de los Derechos de Autor (excepto transmisión de programas de ordenador y acceso a bases de datos), señala el art. 5 de la Directiva 2001/29/CE del Parlamento Europeo y del Consejo, de 22 de mayo de 2001, relativa a la armonización de determinados aspectos de los derechos de autor y derechos afines a los derechos de autor en la sociedad de la información (DDASI), que quedan exentos del derecho exclusivo de reproducción los actos de reproducción provisionales, transitorios o accesorios que formen parte integrante o esencial de un procedimiento tecnológico y cuya finalidad consista, entre otras, en facilitar una transmisión en red entre terceras partes por un intermediario. Por tanto, desde la perspectiva del derecho de autor y respecto a la mayoría de obras que circulan por la red, dichas reproducciones tampoco generan ninguna responsabilidad, en cuanto no atentan contra la exclusiva de sus titulares. 
inviable, sí al menos muy compleja y polémica, una solución consistente en obligar a estos proveedores de acceso y operadores de red a establecer filtros para controlar y retirar contenidos infractores de derechos de terceros, tal y como se ha encargado de poner de manifiesto el TJUE en relación con los programas y sistemas P2P de intercambio de archivos que permiten a los usuarios finales canjear libremente y de forma anónima contenidos no autorizados por los legítimos titulares de derechos (STJUE, 24 de noviembre de 2011, As. C-70/2010, Scarlet; STJUE, 16 de febrero de 2012, As. C-360/2010, Saban, Netlog NV).

\section{Servicios de almacenamiento temporal de datos en memoria caché}

A diferencia de las copias provisionales y transitorias (o efímeras) realizadas por los operadores de redes y acceso para las tareas de transmisión de datos, las copias en memoria tampón o caché de sistema tienen carácter provisional y temporal (lo que denota ya una mayor duración que las meramente efímeras realizadas en los routers de operadores de redes y proveedores de acceso) y tienen además una finalidad diferente.

Desde el punto de vista técnico este almacenamiento temporal no es estrictamente necesario en el proceso de transmisión de datos, pero cumple una importante labor en la aceleración o agilización de las comunicaciones electrónicas, guardando los prestadores de este servicio (normalmente también proveedores de acceso a internet) en sus ordenadores-servidores copias de los datos más solicitados por los usuarios de su sistema, permitiendo su rápida recuperación en búsquedas sucesivas sin tener que acudir a la fuente o sitio en línea del que proviene la información. Como decimos, en la actualidad, los grandes proveedores de caché son los proveedores de acceso a la $\operatorname{Red}^{21}$, aunque se discute también si pueden incluirse en dicho concepto y régimen jurídico ciertos buscadores (como Google Search) que ofrecen servicios de almacenamiento caché para permitir acceder de forma rápida a los resultados de las búsquedas realizadas, mostrando las páginas almacenadas en sus servidores, en lugar de acudir a las originales ${ }^{22}$.

21 A otra escala, y con un sentido totalmente ajeno a la LSSI, el ordenador personal de un usuario actúa como un pequeño proveedor de caché, por cuanto, con la configuración habitual, guarda una copia en memoria de las páginas a las que accede (que es posible, incluso, mantener actualizada con cada conexión a la red aunque no se acceda a la página, la cual se almacena sin que el usuario lo vea), para su recuperación más rápida en caso de que la red esté lenta o sea imposible conectarse (Aparicio, 2003).

22 La Sentencia de la Audiencia Provincial de Barcelona, Secc. 15 , de 17 de septiembre de 2008 (recientemente confirmada por la STS de...), rechaza que el servicio caché del buscador Google pueda tener cabida en el art. 15 LSSICE (art. $13 \mathrm{DCE}$ ), entendiendo que dicho precepto está pensado únicamente para los servicios de system caching que prestan los proveedores de acceso a internet en el marco del proceso de transmisión de datos en internet, reconduciendo la actividad del buscador al régimen de exención de responsabilidad del art. 17 LSSICE. 
El régimen de exención de responsabilidad de los proveedores de System Caching se establece en el art. $13 \mathrm{DCE}^{23}$, incorporado al ordenamiento español en el art. 15 $\mathrm{LSSICE}^{24}$. Son proveedores de caché los intermediarios que transmitan por una red de telecomunicaciones datos facilitados por un destinatario del servicio (el usuario que solicita datos de terceros a través de internet) y los almacenen con la única finalidad de hacer más eficaz su ulterior transmisión (hacia el mismo solicitante y destinatario de dichos datos o cualesquiera otros usuarios del mismo servicio de copia temporal), de forma automática, provisional y temporal ${ }^{25}$. Lo que caracteriza a los proveedores de servicios de caché y les permite, así mismo, beneficiarse del régimen general de exención de responsabilidad, es el carácter automático y no permanente de la operación de almacenamiento, permitida únicamente con el fin establecido en la norma. De acuerdo con las normas citadas, los proveedores de caching no serán responsables por el contenido de los datos almacenados temporalmente en sus sistemas si no modifican la información, permiten el acceso a dicha información solo

23 Memoria tampón (Caching). 1. Los Estados miembros garantizarán que, cuando se preste un servicio de la sociedad de la información consistente en transmitir por una red de comunicaciones datos facilitados por el destinatario del servicio, el prestador del servicio no puede ser considerado responsable del almacenamiento automático, provisional y temporal de esta información, realizado con la única finalidad de hacer más eficaz la transmisión ulterior de la información a otros destinatarios del servicio, a petición de estos, a condición de que: a) el prestador de servicios no modifique la información; b) el prestador de servicios cumpla las condiciones de acceso a la información; c) el prestador de servicios cumpla las normas relativas a la actualización de la información, especificadas de manera ampliamente reconocida y utilizada por el sector; d) el prestador de servicios no interfiera en la utilización lícita de tecnología ampliamente reconocida y utilizada por el sector, con el fin de obtener datos sobre la utilización de la información; y e) el prestador de servicios actúe con prontitud para retirar la información que haya almacenado, o hacer que el acceso a ella sea imposible, en cuanto tenga conocimiento efectivo del hecho de que la información ha sido retirada del lugar de la red en que se encontraba inicialmente, de que se ha imposibilitado el acceso a dicha información o de que un tribunal o una autoridad administrativa ha ordenado retirarla o impedir que se acceda a ella. 2. El presente artículo no afectará a la posibilidad de que un tribunal o una autoridad administrativa, de conformidad con los sistemas jurídicos de los Estados miembros, exija al prestador de servicios poner fin a una infracción o impedirla.

24 Responsabilidad de los prestadores de servicios que realizan copia temporal de los datos solicitados por los usuarios. Los prestadores de un servicio de intermediación que transmitan por una red de telecomunicaciones datos facilitados por un destinatario del servicio y, con la única finalidad de hacer más eficaz su transmisión ulterior a otros destinatarios que los soliciten, los almacenen en sus sistemas de forma automática, provisional y temporal, no serán responsables por el contenido de esos datos ni por la reproducción temporal de los mismos, si: a) no modifican la información; b) permiten el acceso a ella solo a los destinatarios que cumplan las condiciones impuestas a tal fin, por el destinatario cuya información se solicita; c) respetan las normas generalmente aceptadas y aplicadas por el sector para la actualización de la información; d) no interfieren en la utilización lícita de tecnología generalmente aceptada y empleada por el sector, con el fin de obtener datos sobre la utilización de la información; y e) retiran la información que hayan almacenado o hacen imposible el acceso a ella, en cuanto tengan conocimiento efectivo de que ha sido retirada del lugar de la red en que se encontraba inicialmente; que se ha imposibilitado el acceso a ella; o que un tribunal $u$ órgano administrativo competente ha ordenado retirarla o impedir que se acceda a ella.

25 La reproducción efectuada por el proveedor de caché de obras o prestaciones afines protegidas por el derecho de autor quedaría en todo excepcionada del derecho de exclusiva del titular en función de lo establecido por el art. 5 Directiva 2001/29/CE, en cuanto facilita la transmisión en red y una utilización lícita de la obra, aunque en este caso, la exigencia de ausencia de significación económica independiente podría plantear problemas si el proveedor de caching hace una reutilización de esa información al margen de su actividad principal de almacenamiento temporal. 
a los destinatarios de esta a quienes haya autorizado el proveedor original, mantienen actualizada la información almacenada conforme a las reglas aceptadas por el sector, no interfieren en la utilización de la tecnología habitual para obtener datos sobre la utilización de la información, y retiran la información en cuanto tenga conocimiento de que se ha retirado del servidor original (bien por voluntad del propio proveedor, o bien por orden de un tribunal u órgano administrativo).

En suma, el proveedor de caché debe garantizar la integridad de los datos y su actualización, quedando sometido a las decisiones que sobre dicha información tomen el proveedor original y los jueces y tribunales. Sus posibilidades de control sobre la licitud de los contenidos que almacena es muy inferior a la de un proveedor de espacio, pues se realiza de forma automática en función de las exigencias de todos los participantes en el tráfico electrónico. No obstante, si por cualquier circunstancia se modificaran los datos que almacena poniéndolos a disposición del público en forma distinta a la que los ofrece el prestador de servicios y responsable de los mismos, se presume que puede causar un daño a estos, y es susceptible de resarcimiento originando su responsabilidad personal.

Por lo que respecta a la actualización de la información almacenada, existe consenso generalizado en que dicho requisito exonerador de responsabilidad debe interpretarse de forma flexible, debido a la dificultad para sustituir automáticamente toda las informaciones almacenadas al tiempo de cambiar las originales (piénsese, sin ir más lejos, en las páginas de brokers online o de agencias de viajes online, donde la información está cambiando permanentemente). Por lo tanto, aunque hoy día existen herramientas o técnicas para permitir una modificación rápida de la información almacenada (mirroring), puede decirse que no toda ausencia de actualización genera inmediatamente responsabilidad del proveedor de caché. En cualquier caso, la obligación de actualización supone exigir un estándar de diligencia cuantificable en función de las normas de la profesión (la lex artis) y, como tal, superior a la diligencia media; de modo que, si el proveedor, de forma negligente, mantiene la información almacenada una vez que esta haya sido retirada del servidor inicial, por la causa que fuere, incurrirá en responsabilidad, siempre que entre la negligente falta de actualización y el daño causado exista relación de causalidad, y este derive de aquella (Clemente, p. 77; Aparicio, p. 107).

\section{Servicios de alojamiento de datos}

La actividad de los servicios de alojamiento o almacenamiento de datos, proveedores de espacio, sin duda, es la más compleja y polémica de todos los servicios de intermediación en orden a la violación de derechos e intereses de terceros, pues es en los ordenadores o servidores de estos servicios donde se almacenan los contenidos ilícitos y desde donde se ponen a disposición de terceros contenidos no autorizados, virus, injurias calumnias, y entre otros que ocasionan daños a terceros.

El servicio que suministran los prestadores de servicios de alojamiento o almacenamiento de datos consiste en la puesta a disposición del destinatario del servicio (otro prestador de servicios de la sociedad de la información, un particular) de un espacio en sus ordenadores (servidores) para que este pueda utilizarlo, a su vez, 
para sus propias actividades. En dicho espacio, el destinatario almacena de forma más o menos permanente sus mensajes de correo electrónico, sus sitios o páginas web o los contenidos electrónicos que ponen a disposición del público en la internet. Puede comprenderse perfectamente, entonces, el papel fundamental que juegan los proveedores de espacio de alojamiento en el funcionamiento de la red; en particular, ofreciendo a empresarios, profesionales y particulares, la posibilidad de "subir" sus contenidos a la red. Y podrá comprenderse igualmente la sensible posición que ocupan en el ámbito de la responsabilidad de intermediarios, pues con su actividad facilitan muchas de las infracciones de derechos cometidas en internet.

En los servicios de hosting o housing es donde mejor se aprecia la tensión subyacente al debate prelegislativo sobre la responsabilidad o exención de responsabilidad de los intermediarios de la sociedad de la información, pues un estricto régimen de responsabilidad o de supervisión de los actos de los usuarios colapsaría la red, dejando reducidos a unos pocos servicios (normalmente ofrecidos desde paraísos fiscales e informáticos) esta actividad fundamental; mientras que un régimen de exención plena de responsabilidad dejaría impunes muchos servicios que, en lugar de limitarse a ofrecer un servicio técnico automático, neutral y pasivo, contribuyen activamente a las infracciones de derechos de terceros (sobre todo en el ámbito de la propiedad intelectual e industrial).

Así las cosas, siguiendo la línea marcada por el ordenamiento estadounidense (Sect. 512c 17 USC), el art. $14 \mathrm{DCE}^{26}$ y el art. $16 \mathrm{LSSICE}^{27}$ han optado por el eclecticismo más tibio, partiendo de un principio general de exención de responsabilidad por los

26 Alojamiento de datos. 1. Los Estados miembros garantizarán que, cuando se preste un servicio de la sociedad de la información consistente en almacenar datos facilitados por el destinatario del servicio, el prestador de servicios no pueda ser considerado responsable de los datos almacenados a petición del destinatario, a condición de que: a) el prestador de servicios no tenga conocimiento efectivo de que la actividad a la información es ilícita y, en lo que se refiere a una acción por daños y perjuicios, no tenga conocimiento de hechos o circunstancias por los que la actividad o la información revele su carácter ilícito, o de que; b) en cuanto tenga conocimiento de estos puntos, el prestador de servicios actúe con prontitud para retirar los datos o hacer que el acceso a ellos sea imposible. 2. El apartado $1^{\circ}$ no se aplicará cuando el destinatario del servicio actúe bajo la autoridad o control del prestador de servicios. 3. El presente artículo no afectará la posibilidad de que un tribunal o una autoridad administrativa, de conformidad con los sistemas jurídicos de los Estados miembros, exijan al prestador de servicios de poner fin a una infracción o impedirla, ni a la posibilidad de que los Estados miembros establezcan procedimientos por los que se rija la retirada de datos o impida el acceso a ellos.

27 Responsabilidad de los prestadores de servicios de alojamiento o almacenamiento de datos. 1. Los prestadores de un servicio de intermediación consistente en albergar datos proporcionados por el destinatario de este servicio no serán responsables por la información almacenada a petición del destinatario, siempre que: a) No tengan conocimiento efectivo de que la actividad o la información almacenada es ilícita o de que lesiona bienes o derechos de un tercero susceptibles de indemnización; o b) Si lo tienen, actúen con diligencia para retirar los datos o hacer imposible el acceso a ellos.

Se entenderá que el prestador de servicios tiene el conocimiento efectivo a que se refiere el párrafo a) cuando un órgano competente haya declarado la ilicitud de los datos, ordenado su retirada o que se imposibilite el acceso a los mismos, o se hubiera declarado la existencia de la lesión, y el prestador conociera la correspondiente resolución, sin perjuicio de los procedimientos de detección y retirada de contenidos que los prestadores apliquen en virtud de acuerdos voluntarios y de otros medios de conocimiento efectivo que pudieran establecerse. 2. La exención de responsabilidad establecida en el apartado $1^{\circ}$ no operará en el supuesto de que el destinatario del servicio actúe bajo la dirección, autoridad o control de su prestador. 
datos alojados en servicios de "hosting" siempre que el proveedor del servicio: a) no tenga un conocimiento efectivo de la ilicitud de la información almacenada, o de que lesiona bienes o derechos de un tercero susceptibles de indemnización; o b) que, una vez tenido dicho conocimiento, retire de forma diligente los datos o hagan imposible el acceso a ellos.

Por lo tanto, el prestador de servicios de alojamiento de datos podría incurrir en responsabilidad si tuviere conocimiento efectivo de la existencia de contenidos o informaciones ilícitas en sus servidores (se entiende que al tiempo de producirse el alojamiento de estas); o si, una vez adquirido dicho conocimiento (se entiende que a posterior, cuando no tuviera conocimiento de la ilicitud en un primer momento), no procediera diligentemente a su retirada o bloqueara el acceso a estos.

El principal problema para delimitar la responsabilidad del intermediario de servicios de alojamiento reside en establecer qué debe entenderse por "conocimiento efectivo" de la ilicitud de los datos almacenados en su sistema.

Conforme al tenor de la norma, no bastaría la mera sospecha de la actividad ilícita o un conocimiento abstracto de la posibilidad de que se estén lesionando bienes o derechos de terceros, sino que ha de ser un conocimiento actual, real o, como dice la Ley, "efectivo". El art. 16.1, párrafo II, LSSICE, que incorpora al ordenamiento español el art. 14 DCE, establece un concepto más preciso de conocimiento efectivo, disponiendo al efecto que existirá conocimiento efectivo cuando el prestador conozca la correspondiente resolución dictada por un órgano competente (se entiende que judicial o administrativo) que declare la ilicitud de los contenidos y ordene su retirada o que se imposibilite el acceso a estos, así como se da al declarar la existencia de una lesión. Parece presumir, así, que es necesaria una previa resolución judicial o administrativa declarando la ilicitud de un determinado contenido o actividad alojado por el intermediario en su servidor, y que dicha resolución sea notificada al intermediario, momento a partir del cual tendrá "conocimiento efectivo" y resultará obligado a retirar esa información o impedir su acceso a los internautas.

Pero la DCE y LSSICE señalan también que podrá presumirse el conocimiento efectivo de la ilicitud de contenidos alojados por el proveedor de espacio, cuando este tenga lugar como consecuencia de los procedimientos de detección y retirada de contenidos que los prestadores apliquen en virtud de acuerdos voluntarios. A diferencia del ordenamiento estadounidense, donde es obligatoria la implementación de sistemas de notice \& takedown (erigiéndose en pieza clave de todo el sistema de responsabilidad), en Europa se optó por la autorregulación de los prestadores de servicios de intermediación, dejando a su libre voluntad o compromisos adquiridos en códigos de conducta generales o sectoriales, la utilización de estos sistemas de denuncia y retirada. La cuestión es si los prestadores de espacio de alojamiento se mostrarán dispuestos a utilizar estos sistemas si con ello se pueden derivar posibles responsabilidades en caso de no retirar la información o impedir el acceso a la información denunciada como ilícita. De manera que se puede someter sin más al cómodo régimen principal de conocimiento efectivo, y esperar que les 
sea notificada una resolución judicial o administrativa declarando la ilicitud del contenido. Más aún, si estos sistemas pueden dar lugar a conflictos a tres bandas, entre el denunciante titular de derechos presuntamente infringidos, el prestador de alojamiento y el usuario de su servicio que aloja esas informaciones y que podría reclamar responsabilidades al intermediario si retirase información con motivo de una denuncia del titular de derechos que considerase absolutamente infundada o cuando menos dudosa ${ }^{28}$. De modo que el prestador de servicios de alojamiento que decidiera implementar este tipo de servicios de notificación y retirada, podría situarse en el medio de la encrucijada entre, de un lado, los derechos al honor, la intimidad y la propia imagen, propiedad industrial e intelectual, y de otro lado, los derechos a la libertad de expresión e información.

Por último, la Ley menciona que pueden establecerse "otros medios de conocimiento efectivo". Este último inciso actúa como cláusula de cierre de todo el sistema de responsabilidad, ya que como apunta la doctrina, pretende dar legitimidad a cualquier otra práctica que permita probar que el proveedor de alojamiento conocía (o debía conocer sin faltar a la buena fe la ilicitud de los contenidos que albergaban sus servidores. El supuesto paradigmático es la denuncia de la existencia de tales contenidos por parte de los afectados, aunque también puede considerarse el conocimiento público de la más que presunta ilicitud de determinadas informaciones alojadas en un determinado servidor (evidentes muchas veces en el caso de injurias y calumnias contra el honor o ilícitos manifiestos contra derechos de autor y conexos o derechos de marcas y diseños industriales).

El caso es que la legislación comunitaria europea no impone mecanismos de notificación y retirada, ni tampoco explicita formas alternativas de conocimiento efectivo para determinar, en su caso, la responsabilidad de los prestadores de servicios de almacenamiento. Por tanto, a diferencia del ordenamiento estadounidense donde se regula expresamente, es dudoso que la mera notificación de los particulares lleve al "conocimiento efectivo" salvo que así lo haya establecido el propio intermediario en su política detección y retirada de contenidos ilícitos, lo cual parece poco probable. $\mathrm{Y}$ es que el régimen europeo, y en particular el español en el que el conocimiento efectivo depende de la existencia de una resolución judicial o administrativa previa que declare la ilicitud una vez sea comunicada al intermediario de alojamiento, resulta demasiado cómodo para los proveedores de espacio, dejándoles en una situación prácticamente de impunidad.

En un primer momento, el régimen de exención, pensado para intermediarios de la Web 1.0, es decir, cuya actividad es exclusivamente técnica, y que prestan un servicio de alojamiento de datos de forma automática, neutral pasiva, la inexistencia de un deber específico de recepción de denuncias o de cualquier otro comportamiento del que pueda deducirse el conocimiento efectivo, deja al intermediario en una situación muy cómoda, prácticamente de impunidad, como se ha dicho ya, pues

28 Recuérdese que el ordenamiento estadounidense, antes visto, otorga una garantía de no responsabilidad al proveedor de alojamiento siempre que en la retirada de contenidos se ajuste al estricto procedimiento previsto en la Sect. 512 c) 17 USC. 
solo tendrá conocimiento efectivo cuando le sea notificada una resolución judicial o administrativa declarando la ilicitud de la información almacenada, respondiendo únicamente si no reacciona diligentemente retirando esa información o bloqueando el acceso (incluso se ha llegado a discutir si no existe infracción al deber de reacción diligente cuando el intermediario es notificado informalmente de la existencia de dicha resolución por el titular de derechos o por quien represente sus intereses, apuntando que solo debería reaccionar cuando reciba una notificación formal por parte del tribunal u órgano administrativo). Como veremos en la segunda parte de este trabajo, el clima de impunidad se tornó absolutamente injustificable al aparecer la Web 2.0 y proliferar servicios de alojamiento de datos y actividades cuya función no siempre puede calificarse como estrictamente "técnica" ni, por tanto, neutral, automática y pasiva.

Por lo demás, tanto el art. 14.2 DCE como el art. 16.2 LSSICE establecen que no operará la exención de responsabilidad si el destinatario del servicio de alojamiento (es decir, el responsable de los contenidos almacenados) actúa bajo la dirección, autoridad o control del proveedor de espacio. La imputación de responsabilidad deriva en este caso no de la existencia de un conocimiento efectivo de la ilicitud de los datos almacenados por los usuarios o destinatarios del servicio de alojamiento, sino de la relación que une a ambos sujetos, presumiéndose un control jurídico o económico del intermediario sobre el destinatario del servicio. Se trata, en suma, de un supuesto específico de responsabilidad por hecho ajeno (art. 1903 CC), llevado a cabo por un "agente" contractual o extracontractual del proveedor de alojamiento.

\section{Motores de búsqueda y provisión de enlaces}

Como antes se expuso, el art. 17 LSSICE $^{29}$ recoge un supuesto adicional de responsabilidad (o no) de intermediarios de la sociedad de la información; el de los proveedores de servicios de búsqueda y enlaces, no incluidos inicialmente en la DCE, aunque sí en la DMCA estadounidense.

29 Responsabilidad de los prestadores de servicios que faciliten enlaces a contenidos o instrumentos de búsqueda. 1. Los prestadores de servicios de la sociedad de la información que faciliten enlaces a otros contenidos o incluyan en los suyos directorios o instrumentos de búsqueda de contenidos no serán responsables por la información a la que dirijan a los destinatarios de sus servicios, siempre que: a) No tengan conocimiento efectivo de que la actividad o la información a la que remiten o recomiendan es ilícita o de que lesiona bienes o derechos de un tercero susceptibles de indemnización, o; b) Si lo tienen, actúen con diligencia para suprimir o inutilizar el enlace correspondiente. Se entenderá que el prestador de servicios tiene el conocimiento efectivo a que se refiere el párrafo a cuando un órgano competente haya declarado la ilicitud de los datos, ordenado su retirada o que se imposibilite el acceso a los mismos, o se hubiera declarado la existencia de la lesión, y el prestador conociera la correspondiente resolución, sin perjuicio de los procedimientos de detección y retirada de contenidos que los prestadores apliquen en virtud de acuerdos voluntarios y de otros medios de conocimiento efectivo que pudieran establecerse. 2. La exención de responsabilidad establecida en el apartado $1^{\circ}$ no operará en el supuesto de que el proveedor de contenidos al que se enlace o cuya localización se facilite actúe bajo la dirección, autoridad o control del prestador que facilite la localización de esos contenidos. 
El régimen jurídico de la responsabilidad de prestadores de servicios de búsqueda y provisión de enlaces es muy similar, prácticamente idéntico al de los prestadores de servicios de alojamiento, pues no en vano un buscador o un proveedor de directorios de enlaces frecuentemente ofrece también alojamiento en su sitio en línea a las comunicaciones de terceros prestadores de servicios de la sociedad de la información (Carbajo, 2004).

Ambas actividades están vinculadas, pudiendo encontrar buscadores generalistas que ofrecen todo tipo de informaciones localizadas en la red a través de complejos algoritmos matemáticos, o bien informaciones específicas (v.gr., enlaces de prensa) donde los criterios de búsqueda están restringidos. Pero es posible también encontrar servicios en línea que solo ofrecen directorios de enlaces, sin ofrecer al público (aunque puedan disponer internamente de él para su actividad) un motor de búsqueda. $\mathrm{Y}$ es que los proveedores de enlaces pueden hacer también una labor de selección de contenidos, mostrando solo enlaces a páginas o contenidos que sean conformes con los criterios de búsqueda avanzada que hayan sido previamente definidos por el usuario o directamente por el propio proveedor.

Los motores de búsqueda se basan, como decimos, en algoritmos matemáticos que actúan de forma automática, por lo que nada pueden saber, a priori, de la licitud o ilicitud de los contenidos enlazados. Parecía lógico, por tanto, exonerar de responsabilidad, a priori, a los responsables de estos servicios. Y así lo hace el art. 17 LLSICE española, eximiendo de responsabilidad a los intermediarios que ofrecen servicios de búsqueda y enlaces por la información a la que dirijan a los usuarios (destinatarios) de sus servicios siempre que: a) no tengan conocimiento efectivo de que la actividad o la información a la que remiten o recomiendan es ilícita o que lesiona derechos susceptibles de indemnización; o b) si tienen conocimiento efectivo, actúen diligentemente en la supresión o inutilización del enlace correspondiente.

Son dos, por tanto (como en el caso de los proveedores de espacio de alojamiento), los hechos generadores de responsabilidad: no tener conocimiento efectivo de la ilicitud de la información enlazada, o, en caso de tenerlo, no reaccionar diligentemente para su retirada.

Nuevamente la clave reside en qué debe entenderse por "conocimiento efectivo". Respecto a su significación, reproduciendo el párrafo segundo del art. 17.1 LSSICE los mismos elementos recogidos en el art. 16 LSSICE y comentados más arriba, con pequeñas adaptaciones por razón de la distinta actividad de los prestadores de servicios de búsqueda y enlaces. Igualmente, se deja constancia el art. 17.2 LSSICE de que el prestador de servicios de enlaces no se beneficiará de la exención si el destinatario de los mismos actúa bajo su dirección, autoridad o control.

Como se expusiera antes, de acuerdo con su tenor literal el art. 17 LSSICE es aplicable también a quienes no son, en rigor, prestadores de servicios de intermediación, sino a todos los prestadores de servicios de la sociedad de la información que ofrezcan servicios de búsqueda y directorios de enlaces, siempre que esa actividad constituya una actividad económica para el prestador (en coherencia 
con la definición general de prestador de servicios de la sociedad de la información que ofrece el Anexo LSSICE).

Como se ha encargado de señalar la mejor doctrina (Aparicio, 2003, p. 114.), la esencia de internet está en la navegación mediante enlaces, por lo que una regulación que no previera una general autorización de estos, con las oportunas limitaciones de las técnicas de enlaces contrarias a intereses dignos de protección, sería contraria a la propia naturaleza del fenómeno regulado y, como tal, habitualmente infringida.

No obstante, cuando esos enlaces no se generan de forma automática por un buscador, puede presumirse la concurrencia de cierta actividad humana en su selección y puesta a disposición, con lo cual será más fácil, llegado el caso, presumir la existencia de un conocimiento efectivo de la ilicitud de los datos o informaciones enlazados por parte del proveedor. En la Web 2.0 el debate sobre el conocimiento efectivo de la ilicitud y la forma de obtenerlo se torna fundamental (de cara a servicios como Google, AdWords, eBay o cualquiera de las webs de enlaces que ofrecen la descarga directa de archivos con copias no autorizadas de obras o prestaciones afines protegidas por derechos de autor), como vamos a ver en la segunda parte de este trabajo. En estos casos, los proveedores de enlaces son al mismo tiempo proveedores de espacio web para el alojamiento de estos enlaces por parte de los usuarios, confundiéndose así ambas actividades (pues los enlaces no son generados por el intermediario sino proporcionados por los usuarios de su servicio), aunque generalmente se reconducen hacia la actividad conocida como "Hosting Web 2.0".

\section{REFERENCIAS}

Aparicio, J. P. (2003). El nuevo régimen de prestación de servicios de la sociedad de la información. Revista de Derecho y Nuevas Tecnologías, (2), 87-111.

Barceló, J. y Koelman, K.J. (2000). La responsabilidad de los intermediarios de internet en la directiva de comercio electrónico: problemas no resueltos. $R C E$, (6), 3-32.

Busto, J. M. (2003). La responsabilidad civil de los prestadores de servicios de la sociedad de la información (ISPs)". En L.F Reglero Campos (Ed.). Tratado de responsabilidad civil, T. II, (pp. 971-995). Navarra: Thomson-Aranzadi.

Carbajo, F. (2004). La responsabilidad por hiperenlaces e instrumentos de búsqueda en internet. Práctica Derecho Daños: Revista de Responsabilidad Civil y Seguros, 2(20), 7-29.

Clemente, M. (2003). La responsabilidad civil de los prestadores de servicios de la sociedad de la información". En C. Meoro y S. Cavanillas (Eds.). Responsabilidad civil y contratos en internet. Su regulación en la Ley de Servicios de la Sociedad de la Información y de Comercio Electrónico (pp. 1-116). Granada: Comares.

Garrote, I. (2000). La responsabilidad civil extracontractual de los prestadores de servicios en línea por infracciones de los derechos de autor y conexos. Revista 
de Propiedad Intelectual, (6), 9-64.

González, A. (2006). Modificaciones que afectan a los medios de tutela de la propiedad intelectual. En Bercovitz Rodríguez-Cano, R. (Coord.). Las reformas de la Ley de Propiedad Intelectual. Valencia: Tirant lo Blanch.

Ley 34/2002, de 11 de julio, de Servicios de la Sociedad de la Información y del Comercio Electrónico (LSSICE).

Moncada, J. P. (2009). La responsabilidad de los prestadores de servicios de intermediación en la sociedad de la información. Granada: Universidad de Granada.

Parlamento Europeo y del Consejo. Anexo de la Ley 34/2002, de 11 de julio, de Servicios de la Sociedad de la Información y del Comercio Electrónico; LSSICE), que trae razón de la legislación comunitaria europea (Directiva 2000/31/CE, de 8 de junio, del Parlamento Europeo y del Consejo.

Peguera, M. (2007). La exclusión de responsabilidad de los intermediarios en internet. Granada: Comares.

Rubí, A. (2010). Derecho al honor online y responsabilidad civil de los ISPs, InDret. Recuperado de www.indret.com

Unión Europea (2011). Sentencia del Tribunal de Justicia. As. C-70/2010, Scarlet (24 noviembre, 2011).

Unión Europea (2012). Sentencia del Tribunal de Justicia. As. C-360/2010, SABAN c. Netlog NV (16 febrero, 2012). 